\title{
Autokorelasi Spasial Untuk Analisis Pola Pengawasan Kawasan Lindung Di Kota Ambon Maluku
}

\author{
Anna Simatauw \\ Magister Sistem Informasi \\ Universitas Kristen Satya Wacana \\ annasimatauw2504@gmail.com
}

\author{
Eko Sediyono \\ Magister Sistem Informasi \\ Universitas Kristen Satya Wacana \\ ekosed1@yahoo.com
}

\author{
Sri Yulianto Joko Prasetyo \\ Magister Sistem Informasi \\ Universitas Kristen Satya Wacana \\ sri.yulianto@staff.uksw.edu
}

\begin{abstract}
Abstrak - Kota Ambon memiliki kawasan lindung yang ditetapkan untuk melindungi kelestarian lingkungan dan sangat sensitif terhadap dampak negatif untuk memenuhi kebutuhan manusia dalam penggunaan lahan. Penelitian ini bertujuan untuk menganalisis pola pengawasan kawasan lindung dalam bentuk data perubahan penutupan lahan pada 50 wilayah di Kota Ambon dengan menggunakan uji autokorelasi indeks Global Moran's I dan Local Indicator of Spatial Association (LISA), selanjutnya melakukan peramalan pola spasial pada data perubahan penutupan lahan di tahun 2020 . Penelitian ini menunjukkan terdapat autokorelasi spasial dari perubahan penutupan lahan untuk kawasan lindung tetapi korelasi melemah dengan nilai indeks Moran's I berubah dari 0,283362665 menjadi $-\mathbf{0 , 0 4 2 5 2 3 0 5 4}$. Peramalan tahun 2020 menunjukkan terdapat autokorelasi spasial pada tingkat perubahan penutupan lahan yang berkorelasi negatif dengan nilai indeks Moran's I -0,011095491.

Kata Kunci: Autokorelasi Spasial, Global Moran's I, Local Indicator of Spatial Association (LISA), Peramalan.
\end{abstract}

\section{PENDAHULUAN}

Kawasan lindung adalah wilayah yang ditetapkan dengan fungsi utama melindungi kelestarian lingkungan hidup yang mencakup sumber daya alam dan sumber daya buatan [1]. Setiap wilayah tentu memiliki kawasan lindung sebagai kawasan yang ditetapkan dengan fungsi utama melindungi kelestarian sumber daya alam dan sumber daya buatan serta menjaga keseimbangan ekologi kawasan disekitarnya.

Kota Ambon yang sering juga disebut Ambon Manise merupakan sebuah wilayah yang menjadi ibu kota dari Propinsi Maluku. Pemerintah Kota Ambon telah membuat rencana kawasan lindung dalam rencana pola ruang 20112031 dengan menentukan wilayah-wilayah yang diperuntukkan sebagai kawasan lindung. Kawasan lindung sangat peka terhadap pengaruh alam serta dampak negatif yang diakibatkan oleh aktivitas masyarakat dalam memenuhi kebutuhan untuk penggunaan lahan. Hal ini yang mengakibatkan terjadinya kerusakan pada wilayah kawasan lindung dan perubahan struktur serta pemanfaatan kawasan lindung.

Penelitian ini dilakukan pada kawasan lindung di Kota Ambon berdasarkan rencana pola ruang dalam RTRW tahun 2011-2031. Penelitian ini bertujuan untuk mengusulkan pendekatan informasi spasial dalam bentuk pola spasial untuk mencari dan menggambarkan pola pengawasan kawasan lindung di Kota Ambon dengan menggunakan Sistem Informasi Geografis (SIG) dengan melakukan analisis autokorelasi spasial menggunakan indeks Global Moran's I dan indeks Local Indicator of Spatial Association (LISA) untuk memastikan hotspot kawasan lindung berdasarkan data sampling. Selanjutnya akan dilakukan peramalan menggunakan model ARIMA untuk memprediksi pola spasial pada tahun 2020 sebagai alternatif untuk pemecahan masalah pengawasan kawasan lindung yang menghasilkan data geografis sebagai bahan masukan dalam proses pengambilan keputusan. Autokorelasi spasial merupakan penilaian korelasi antar pengamatan atau lokasi pada suatu variabel yang akan menunjukkan apakah kawasan yang diamati memiliki ruang yang terkait dengan kawasan yang berdekatan [2]. Dalam penelitian ini yang akan menjadi fokus yaitu pola spasial highhigh ditunjukkan dengan warna merah pada wilayah pengamatan yang merupakan kawasan dengan tingkat perubahan penutupan lahan tinggi.

Hasil dari analisis akan menjadi sebuah konsep berbasis pola spasial yang dapat digunakan oleh instansi terkait untuk proses pengambilan keputusan dalam melakukan evaluasi dan manajemen pemanfaatan kawasan lindung dalam rencana pola ruang yang meliputi kawasan lindung.

\section{TINJAUAN PUSTAKA}

A. Penelitian Terdahulu

Ma, dkk. dalam penelitian yang berjudul "Analysis of Land Use Patterns and Human Causes Based on Spatial Autocorrelation" menganalisis pola autokorelasi spasial penggunaan lahan dan mengeksplorasi dampak manusia pada pembentukan pola [3]. Metode yang digunakan yaitu autokorelasi spasial global dan Local Indicator of Spatial Association (LISA). Hasil dari penelitian ini menunjukkan bahwa Propinsi Yunnan sebagai propinsi perbatasan yang 
terbelakang di Cina menunjukkan akumulasi lahan konstruksi yang signifikan dan berpengaruh besar terhadap lahan ekologis.

Hsu, dkk. dalam penelitian yang berjudul "The Path of Crowd Dominated-Motion Detection Based on Spatial Autocorrelation" mengusulkan model grid untuk menggambarkan distribusi kerumunan dalam area yang di ukur [4]. Metode Global Moran's I digunakan untuk menentukan apakah distribusi kerumunan di daerah yang diukur adalah dispersi atau agregasi. Hasil penelitian menunjukkan jalur gerakan yang didominasi orang banyak dapat ditentukan secara efisien. Metode ini dapat digunakan untuk mendeteksi jalur dominan gerakan kerumunan dan menyediakan informasi spasial yang berharga untuk perencanaan dan manajemen ruang, yang berlaku untuk ruang publik dalam pengawasan keamanan dan perencanaan tata ruang pameran.

Niu, dkk. dalam penelitian yang berjudul "Land-Use Degree and Spatial Autocorrelation Analysis in Kunming City Based on Big Data" menerapkan teori korelasi spasial pada big data interpretasi citra penginderaan jauh ENVI dan penggunaan lahan dari 14 kabupaten di Kunming untuk menganalisis autokorelasi spasial dan tingkat penggunaan lahan pada tahun 2005, 2011, dan 2015 dengan menggunakan Indeks Moran's I [5]. Penelitian ini menunjukkan: (1) Pangsa lahan yang ditanami dan tutupan vegetasi besar, tetapi luas lahan yang ditanami semakin menurun sementara lahan konstruksi semakin meningkat, (2) Terdapat autokorelasi spasial pada penggunaan lahan, tetapi korelasinya melemah. (3) Ada pengelompokan autokorelasi spasial lokal termasuk empat jenis: tinggi-tinggi $(\mathrm{HH})$, rendah-rendah (LL), tinggirendah (HL), dan rendah tinggi (LH) tetapi aglomerasi melemah.

Dalam penelitian ini hasil perhitungan Moran's $I$ akan divisualisasikan ke bentuk peta LISA dalam mengidentifikasi pola spasial pengawasan kawasan lindung berdasarkan sampel dalam bentuk data perubahan penutupan lahan tahun 2011-2017, apakah perubahan penutupan lahan untuk kawasan lindung di suatu wilayah memiliki kaitan dengan kawasan lindung di wilayah sekitarnya atau tidak, selanjutnya dilakukan peramalan untuk memprediksi pola spasial pada tahun 2020 .

\section{B. Dasar Teori}

Autokorelasi spasial merupakan salah satu analisis spasial yang didefinisikan sebagai peniliaian korelasi untuk mengetahui korelasi antar lokasi pengamatan pada suatu variabel. Jika antar lokasi pengamatan menunjukkan saling ketergantungan terhadap ruang, maka data tersebut dikatakan terautokorelasi secara spasial. Autokorelasi spasial positif mengindikasikan lokasi yang berdekatan mempunyai nilai yang mirip dan cenderung berkelompok. Autokorelasi spasial negatif mengindikasikan lokasi yang berdekatan mempunyai nilai yang berbeda dan cenderung menyebar. Sedangkan untuk yang tidak ada, autokorelasi spasial mengindikasikan pola lokasi acak. Indikator autokorelasi spasial dapat dibagi menjadi dua kategori, yaitu indeks global dan indeks lokal [6]. Dalam penelitian ini digunakan indeks Global Moran's I untuk menilai interaksi spasial dalam data dan indeks Local Indicator of Spatial Association (LISA) untuk menilai asosiasi pola di sekeliling individu dan melihat sejauh mana pola global tergambar dalam data.

Global Moran's I adalah ukuran autokorelasi spasial yang dikembangkan oleh Patrick Alfred Pierce Moran pada tahun 1950. Global Moran's I digunakan untuk melakukan uji depedensi spasial atau autokorelasi antar lokasi pengamatan. Global Moran's I merupakan metode autokorelasi spasial yang paling sering digunakan untuk mengindikasikan pola spasial. Global Moran's I dihitung menggunakan persamaan (1) untuk melihat nilai autokorelasi spasial. Hasil Moran's I dapat digunakan untuk menguji apakah terdapat autokorelasi spasial di wilayah penelitian.

$$
I=\frac{n \Sigma_{i=1}^{n} \Sigma_{j=1}^{n} w_{i j}\left(x_{i}-\bar{x}\right)\left(x_{j}-\bar{x}\right)}{\sum_{i=1}^{n} \Sigma_{j=1}^{n} w_{i j} \Sigma_{i=1}^{n}\left(x_{i}-\bar{x}\right)^{2}}
$$

Dimana:

$$
\begin{aligned}
I & =\text { indeks Moran's } I \\
\mathrm{n} & =\text { jumlah wilayah studi kasus } \\
\mathrm{x}_{\mathrm{i}} & =\text { nilai lokasi ke-i }(\mathrm{i}=1,2, \ldots, \mathrm{n}) \\
\mathrm{x}_{\mathrm{j}} & =\text { nilai lokasi ke-j }(\mathrm{j}=1,2, \ldots, \mathrm{n}) \\
\overline{\mathrm{x}} & =\text { rata-rata data } \\
\mathrm{w} & =\text { matriks pembobot }
\end{aligned}
$$

$E(I)=\frac{-1}{n-1}$

Pada Persamaan (2), E(I) adalah nilai ekspektasi Moran's $I$ dan n merupakan jumlah area pengamatan sebanyak 50 area pada penelitian ini. Nilai ekspektasi Moran's I menunjukkan jika nilai I > E(I) maka autokorelasi adalah positif atau pola spasial yang terbentuk adalah pola cluster (mengelompok), sedangkan jika nilai $\mathrm{I}<\mathrm{E}(\mathrm{I})$ autokorelasi bernilai negatif atau pola dispersed (menyebar) dan jika nilai $\mathrm{I}=\mathrm{E}(\mathrm{I})$ artinya tidak ada autokorelasi spasial.

Local Indicator of Spatial Association (LISA) berhubungan dengan Moran Scatterplot. LISA adalah komponen versi sebelumnya dari Moran's I yang dihitung menggunakan persamaan (3). Autokorelasi spasial lokal (LISA) memungkinkan identifikasi jenis kluster yaitu HighHigh pada kuadran pertama Moran Scatterplot, Low-Low pada kuadran ketiga Moran Scatterplot, Low-High pada kuadran kedua Moran Scatterplot, dan High-Low pada kuadran keempat Moran Scatterplot. Salah satu kelemahan adalah bahwa ia mengidentifikasi kluster outlier tanpa menunjukkan apakah terdiri dari nilai tinggi atau nilai rendah [7].

$I_{i}=z_{i} \sum_{j}^{n} W_{i j} Z_{j}$

Dimana:

$$
\begin{array}{ll}
\mathrm{n} & =\text { jumlah wilayah studi kasus } \\
\mathrm{Z}_{\mathrm{i}} \text { dan } \mathrm{Z}_{\mathrm{j}} & =\text { deviasi dari nilai rata-rata } \\
\mathrm{W} & =\text { matriks pembobot }
\end{array}
$$


Peramalan (forecasting) merupakan ilmu dalam memprediksi sesuatu yang belum terjadi dengan menggunakan data-data dari masa lalu yang bertujuan untuk memprediksi peristiwa yang akan terjadi di masa depan [8]. Dalam penelitian ini model Autoregresif Integrated Moving Average (ARIMA) yang merupakan model dari metode runtun waktu (time-series) akan digunakan untuk melakukan proses peramalan.

\section{METODOLOGI PENELITIAN}

A. Gambaran Umum Lokasi Studi Kasus

Penelitian ini dilakukan di Kota Ambon yang terletak di sebagian besar wilayah Pulau Ambon, Propinsi Maluku pada 5 kecamatan yaitu: Kecamatan Sirimau, Teluk Ambon Baguala, Teluk Ambon, Leitimur Selatan, dan Nusaniwe yang terdiri dari 20 kelurahan, 23 negeri, dan 7 desa (Gambar 1). Kota Ambon teretak di $3^{\circ}-4^{\circ}$ LS dan $128^{\circ}-129^{\circ}$ BT, dimana secara keseluruhan Kota Ambon berbatasan dengan Kabupaten Maluku Tengah. Sesuai Peraturan Pemerintah Nomor 13 Tahun 1979, luas wilayah Kota Ambon seluruhnya $377 \mathrm{Km}^{2}$ [9].

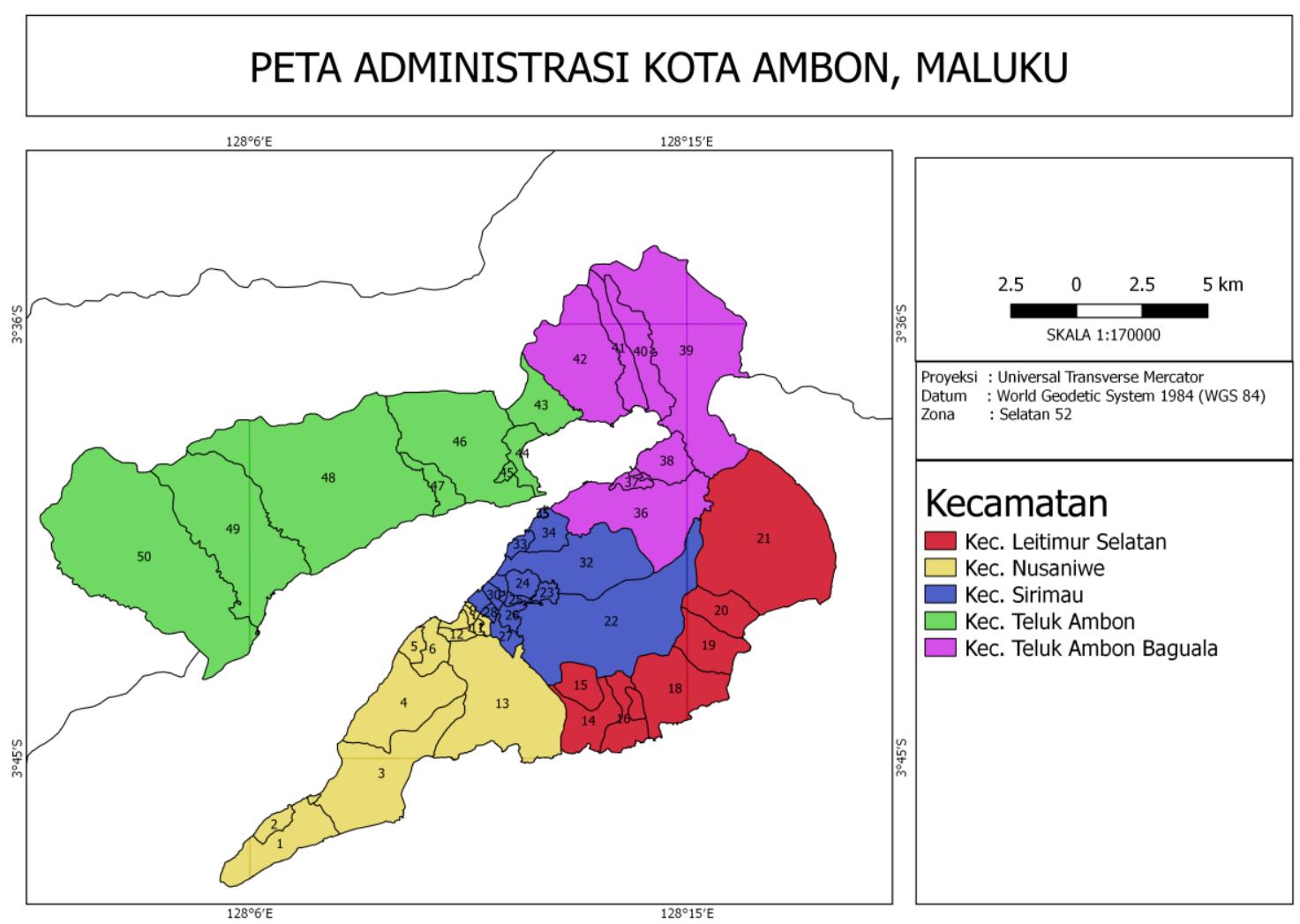

Gambar 1. Peta Administrasi Kota Ambon.

Tabel 1. Daftar Kelurahan, Desa dan Negeri Per Kecamatan.

\begin{tabular}{rlrl} 
NO & KEL_DESA & NO & KEL_DESA \\
\hline 1 & Negeri Latuhalat & 26 & Kel. Batu Meja \\
\hline 2 & Negeri Seilale & 27 & Kel. Batu Gajah \\
\hline 3 & Negeri Nusaniwe & 28 & Kel. Ahusen \\
\hline 4 & Negeri Amahusu & 29 & Kel. Honipopu \\
\hline 5 & Kel. Nusaniwe & 30 & Kel. Uritetu \\
\hline 6 & Kel. Benteng & 31 & Kel. Rijali \\
\hline 7 & Kel. Wainitu & 32 & Negeri Batumerah \\
\hline 8 & Kel. Waihaong & 33 & Kel. Pandan Kasturi \\
\hline 9 & Kel. Silale & 34 & Negeri Hative Kecil \\
\hline 10 & Kel. Urimessing & 35 & Desa Galala \\
\hline 11 & Kel. Mangga Dua & 36 & Negeri Halong \\
\hline 12 & Kel. Kuda Mati & 37 & Desa Latta \\
\hline
\end{tabular}




\section{B. Pengumpulan Data}

Pengumpulan data yang dilakukan dalam penelitian yakni pengumpulan data sekunder berupa data perubahan penutupan lahan sebagai pola pengawasan kawasan dan data kawasan lindung dari rencana pola ruang Kota Ambon tahun 20112031 berekstensi file .xls dan peta administrasi untuk pemetaan data dalam bentuk ekstensi file .shp. Sampel data yang akan digunakan untuk analisis adalah data pada tahun 2011-2017 yang diperoleh dari Dinas Kehutanan Provinsi Maluku dan Bappekot Ambon.

C. Pengolahan Data

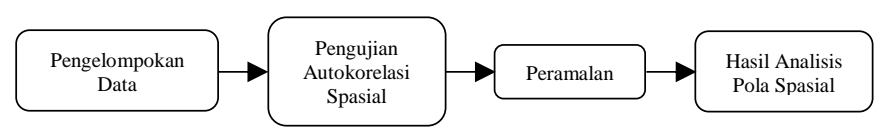

Gambar 2. Proses Pengolahan Data

Pengolahan data pada gambar 2 dijelaskan sebagai berikut:

1. Pengelompokan Data

Tahap pertama akan dilakukan pengelompokan data dengan melakukan proses klasifikasi data perubahan penutupan lahan berdsarkan data kawasan lindung dan diklasifikasi sesuai dengan wilayah administrasi. Hasil klasifikasi akan menjadi data input berekstensi file .csv yang akan digunakan dalam melakukan analisis.

\section{Pengujian Autokorelasi Spasial}

Tahap berikut akan dilakukan pengujian autokorelasi spasial (Gambar 3) untuk menganalisis pola spasial menggunakan indeks Global Moran's I dan indeks Local Indicators of Spatial Association (LISA) dengan bantuan R untuk melakukan Moran test, selanjutnya hasil dari pengujian autokorelasi spasial kemudian di visualisasi dalam bentuk peta LISA untuk menentukan pola spasial (high-high, lowlow, high-low, low-high dan insignificant) pada tahun 2011, 2013, 2015 dan 2017.

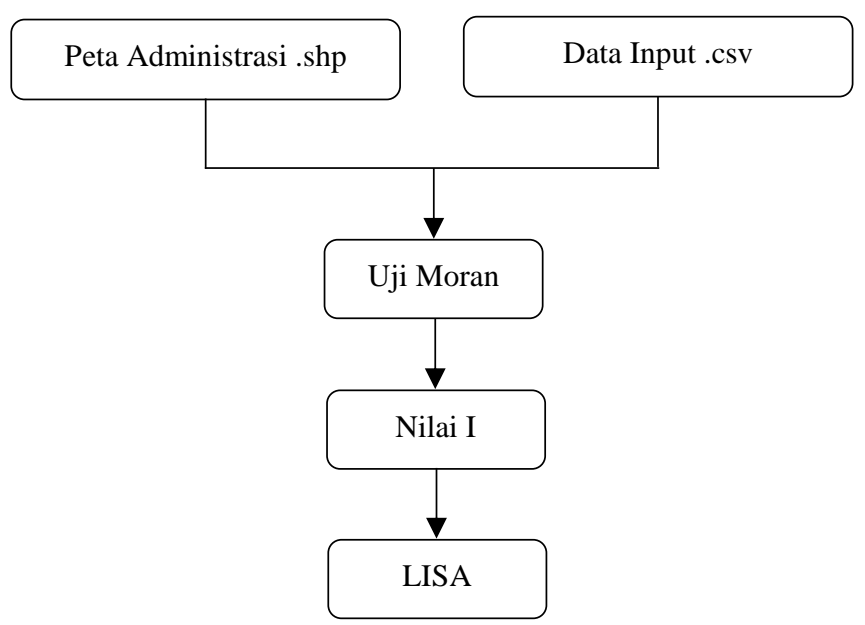

Gambar 3. Diagram Analisis Autokorelasi Spasial.
Pseudocode Global Moran's I

\#Perhitungan Indeks Moran’s I

Start;

filemame $=$ input('data filename'); \#menginput data data $=$ load(filename);

$\mathrm{n}=\operatorname{size}($ data, 1$) ; \quad$ \#jumlah wilayah studi kasus

$\mathrm{x}=\operatorname{data}(:, 1)$;

Clear data;

$\mathrm{d}=\operatorname{pdist}(\mathrm{xy}$, 'euclidean'); \#mengukur jarak $\mathrm{dsq}=\operatorname{squareform}(\mathrm{d})$;

clear d;

numerator $=0$;

denominator $=0$;

xmean $=$ mean $(\mathrm{x})$;

for $\mathrm{i}=1: \mathrm{n}$,

for $\mathrm{j}=1: \mathrm{n}$,

if $(\operatorname{dsq}(i, j) \sim=0)$,

numerator $=$ numerator $+(x(i)-x m e a n) *(x(j)-$ xmean);

denominator $=$ denominator $+(x(i)-x m e a n)^{\wedge} 2$;

end

end

end

\#Menghitung nilai Moran's I

$\mathrm{I}=(\mathrm{n}) *$ numerator / denominator if $\mathrm{I}=\mathrm{E}(\mathrm{I})$

Then $\mathrm{I}=$ "Tidak Ada Autokorelasi" else if $\mathrm{I}<\mathrm{E}(\mathrm{I})$

Then I = "Autokorelasi Positif" else if $\mathrm{I}>\mathrm{E}(\mathrm{I})$

Then I = "Autokorelasi Negatif" end

\section{Peramalan}

Tahap selanjutnya akan dilakukan analisis peramalan untuk memprediksi pola spasial dengan menggunakan model Autoregresif Integrated Moving Average (ARIMA) berdasarkan data runtun waktu dari tahun 2011-2017. Hasil peramalan kemudian akan divisualisasi dalam bentuk peta LISA untuk menampilkan pola spasial yang terbentuk berdasarkan hasil peramalan tahun 2020 .

\section{Hasil Analisis Pola Spasial}

Tahap ini akan dilakukan berdasarkan hasil pengujian autokorelasi spasial serta visualisasi dalam bentuk peta LISA pada area pengamatan dari tahun 2011-2017 serta hasil peramalan tahun 2020. 


\section{HASIL DAN PEMBAHASAN}

\section{A. Pengelompokan Data}

Pengelompokan data dilakukan untuk melihat perubahan penutupan lahan pada kawasan lindung. Hasil pengelompokan data akan dibuat dalam bentuk format file .csv dan digunakan sebagai data analisis untuk melakukan moran test dengan bantuan $\mathrm{R}$.

\section{B. Pengujian Autokorelasi Spasial}

Pengujian autokorelasi spasial dilakukan dengan bantuan $\mathrm{R}$ untuk melakukan moran test dan mendapatkan nilai I untuk menghasilkan peta LISA (Gambar 3). Hasil perhitungan pada tahun 2011, tahun 2013, tahun 2015, dan tahun 2017 ditampilkan dalam Tabel 2 berikut:

Tabel 2. Hasil Perhitungan

\begin{tabular}{rrrc} 
No & Tahun & Nilai (I) & Nilai E(I) \\
\hline 1. & 2011 & 0,283362665 & $-0,020408163$ \\
\hline 2. & 2013 & 0,099272585 & $-0,020408163$ \\
\hline 3. & 2015 & 0,059182736 & $-0,020408163$ \\
\hline 4. & 2017 & $-0,042523054$ & $-0,020408163$ \\
\hline
\end{tabular}

Tabel 2 menampilkan hasil perhitungan perubahan penutupan lahan pada kawasan lindung di Kota Ambon menunjukkan korelasi yang signifikan. Dari tahun 2011 sampai tahun 2015, indeks Moran's I positif, menunjukkan tingkat perubahan penutupan lahan berkorelasi positif. Karakter korelasi spasial positif yaitu, wilayah dengan tingkat perubahan penutupan lahan tinggi cenderung berbatasan dengan wilayah yang tingkat perubahan penutupan lahan tinggi. Dari tahun 2011 hingga 2015, Indeks Moran berubah dari 0,283362665 menjadi 0,059182736 yang berarti korelasi spasial lemah. Pada tahun 2017 nilai indeks Moran 0,042523054 atau bernilai negatif, yang berarti tingkat perubahan penutupan lahan menunjukkan korelasi negatif, yaitu wilayah dengan tingkat perubahan penutupan lahan yang tinggi cederung berbatasan dengan wilayah yang tingkat perubahan penutupan lahan rendah.

\section{Hasil Analisis Local Indicator of Spatial Association (LISA)}

Indeks LISA (Local Indicator of Spatial Association) untuk mengukur pola spasial yang mencerminkan relevansi antara nilai observasi kawasan lokal dan kawasan yang berdekatan disekitarnya juga untuk mengilustrasikan kawasan yang lebih banyak terdapat autokorelasi spasial global. Autokorelasi spasial pada kawasan lindung di visualisasi ke dalam bentuk Peta LISA yang ditampilkan pada Gambar 4

Tahun 2011 wilayah Negeri Laha, Negeri Tawiri dan Negeri Hative Besar pada Kecamatan Teluk Ambon, Desa Passo Kecamatan Teluk Ambon Baguala dan Negeri Hutumuri Kecamatan Leitimur Selatan membentuk pola spasial high-high dikarenakan wilayah dengan penggunaan lahan tinggi untuk kawasan lindung berbatasan dengan wilayah dengan penggunaan lahan tinggi. Berdasarkan RTRW tahun 2011-2031 wilayah-wilayah tersebut merupakan wilayah kawasan hutan lindung terbesar.
Tahun 2013 merupakan hasil analisis kawasan lindung dengan tingkat perubahan penutupan lahan terbesar yang membentuk pola high-high pada Kecamatan Teluk Ambon meliputi Desa Poka dan Desa Hunuth serta di Kecamatan Teluk Ambon Baguala meliputi Keluarahan Lateri, Desa Latta, dan Negeri Halong. Hal ini dikarenakan wilayahwilayah tersebut mengalami perubahan penutupan lahan tinggi pada kawasan bakau, sempadan pantai dan kawasan penyangga yang merupakan kawasan lindung dan dilakukan pembangunan pemukiman serta infrastruktur penunjang ekonomi.

Tahun 2015 pola high-high berpindah ke Negeri Halong Kecamatan Teluk Ambon Baguala, Negeri Soya Kecamatan Sirimau, Negeri Nusaniwe, dan Negeri Latuhalat Kecamatan Nusaniwe yang merupakan kawasan dengan tingkat perubahan penutupan lahan tinggi. Hal ini dikarenakan wilayah tersebut juga mengalami perubahan penutupan lahan tinggi. Beberapa titik kawasan lindung khususnya untuk kawasan penyangga dan sempadan pantai digunakan untuk melakukan pembangunan.

Tahun 2017 pola high-high pada tingkat perubahan penutupan lahan tinggi di Keluarahan Lateri Kecamatan Teluk Ambon Baguala. Hal ini dikarenakan beberapa lokasi kawasan penyangga menjadi tanah terbuka yang akan digunakan untuk melakukan pembangunan.

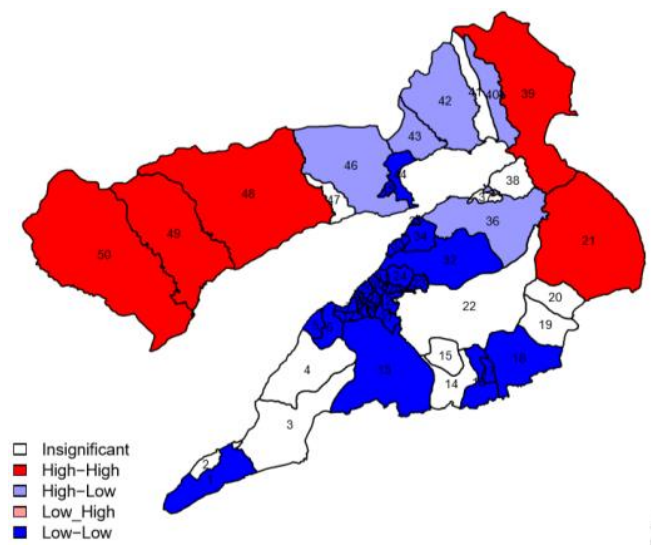

(a) Tahun 2011

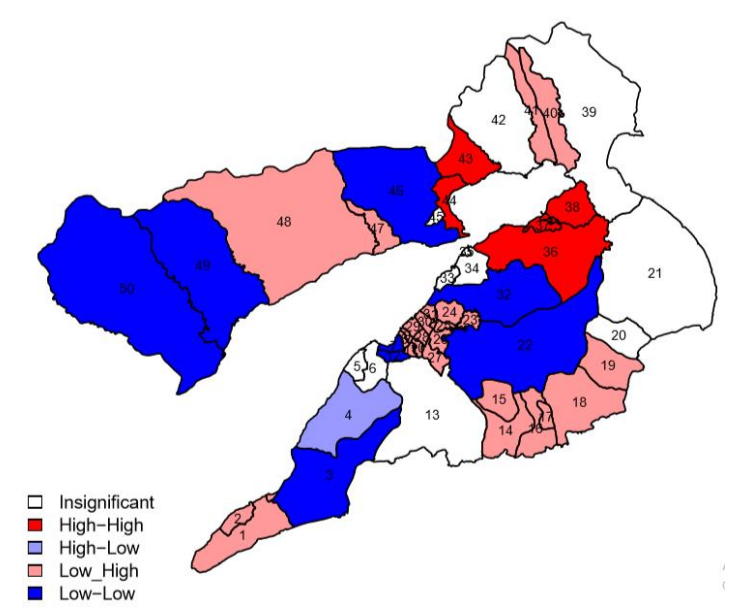

(b) Tahun 2013 


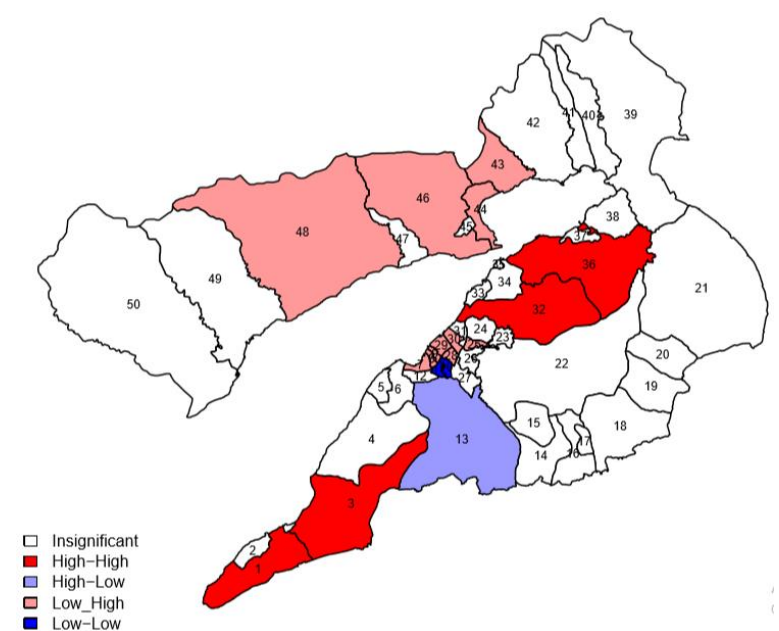

(c) Tahun 2015

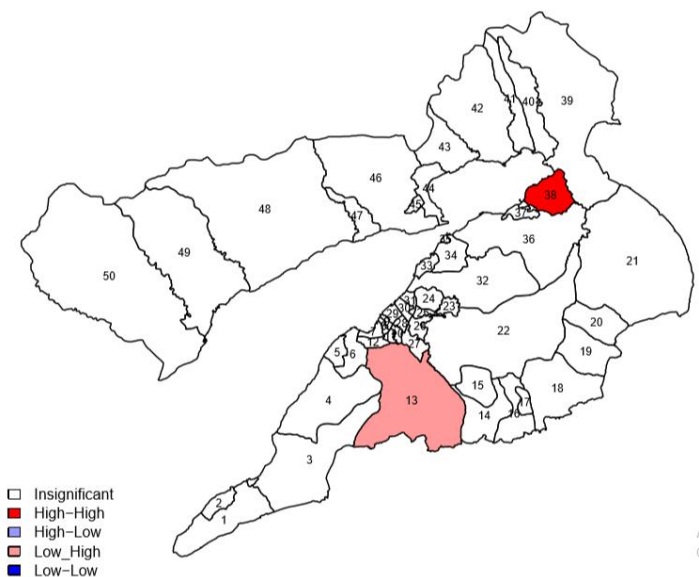

(d) Tahun 2017

Gambar 4. Hasil Analisis LISA Perubahan Penutupan Lahan Kawasan Lindung Pada Tahun 2011, 2013, 2015, dan 2017.

D. Peramalan

Dalam melakukan peramalan, pertama akan ditampilkan grafik perubahan penutupan lahan untuk kawasan lindung dari tahun 2011-2017 (Gambar 5).

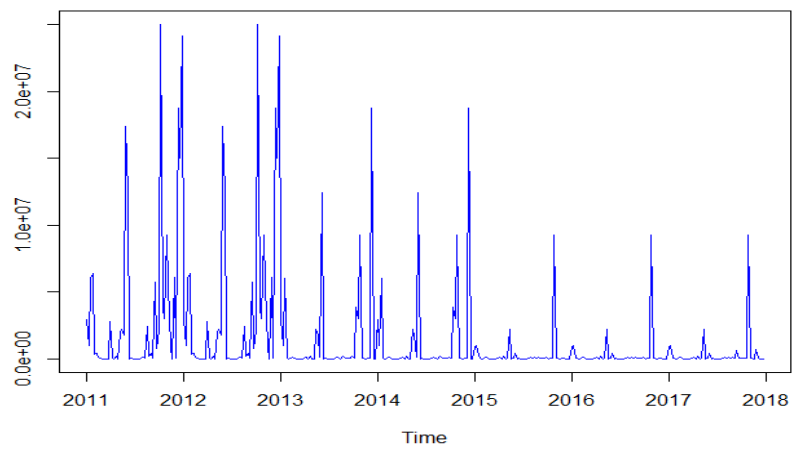

Gambar 5. Grafik Perubahan Penutupan Lahan Tahun 20112017.
Gambar 5 menunjukkan grafik data runtun waktu perubahan penutupan lahan dari tahun 2011-2017. Selanjutnya menentukan nilai Autocorrelation Function (ACF) dan Partial Autocorrelation Function (PACF) dan mendapatkan model ARIMA $(2,1,1)(0,1,2)$ sebagai model terbaik (Gambar 6) yang akan digunakan untuk menentukan nilai order dan seasonal order yang akan menampilkan grafik peramalan (Gambar 7).
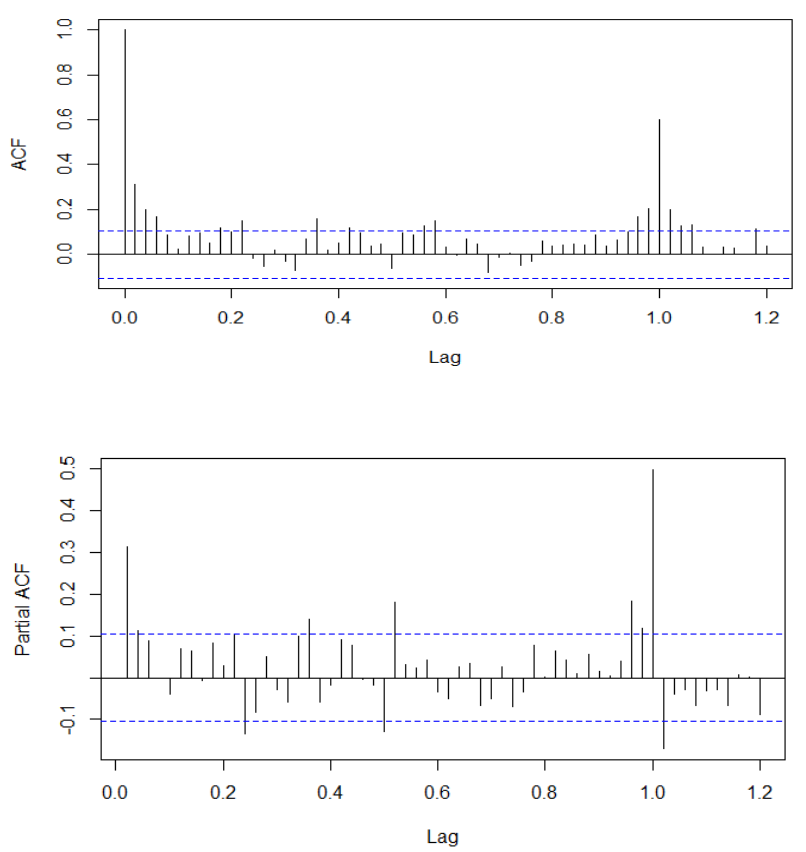

Gambar 6. ACF dan PACF.

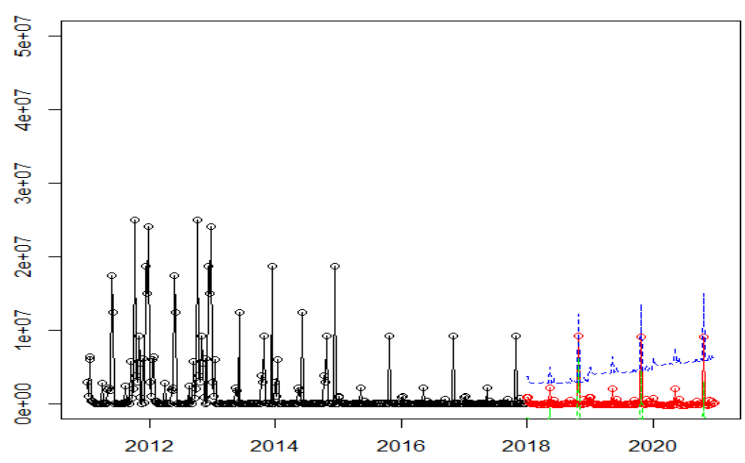

Gambar 7. Grafik Peramalan Tahun 2020.

Gambar 7 menampilkan grafik peramalan perubahan penutupan lahan kawasan lindung selama 3 periode peramalan. Grafik peramalan yang ditandai dengan garis berwarna hitam menunjukkan grafik perubahan penutupan lahan tahun 2011-2017, garis berwarna merah menunjukkan besaran peramalan perubahan penutupan lahan pada tahun 2018-2020, garis berwarna biru merupakan batas atas peramalan, dan garis berwarna hijau merupakan batas bawah peramalan. 
Peramalan tahun 2020 jika di visualisasikan dalam peta LISA (Gambar 8) akan menampilkan peramalan pola spasial tahun 2020 .

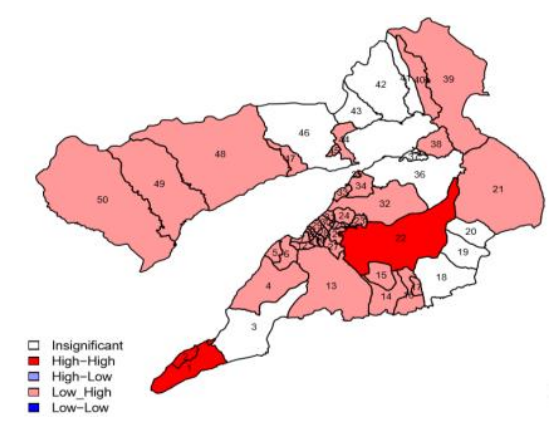

Gambar 8. Visualisasi Peta LISA Peramalan Perubahan Penutupan Lahan Kawasan Lindung Tahun 2020.
Gambar 8 menampilkan hasil peramalan perubahan penutupan lahan kawasan lindung untuk tahun 2020. Hasil peramalan menunjukkan Negeri Latuhalat dan Negeri Seilale pada Kecamatan Nusaniwe dan Negeri Soya di Kecamatan Sirimau membentuk pola spasial high-high yang berarti tingkat perubahan penutupan lahan berkorelasi negatif dengan nilai Morans's I -0,011095491.

E. E. Hasil Analisis Pola Spasial

Hasil analisis pola spasial dari tahun 2011-2017 serta hasil peramalan tahun 2020 ditampilkan pada Tabel 3. Pada Tabel 3 ditampilkan hasil analisis pola spasial yang terbentuk dari setiap area pengamatan pada tahun 2011-2017 serta peramalan pola spasial untuk tahun 2020. Pola spasial highhigh menunjukkan wilayah dengan perubahan penutupan lahan tinggi.

Tabel 3. Hasil Analisis Pola Spasial.

\begin{tabular}{|c|c|c|c|}
\hline No. & Tahun & Area Pengamatan & $\begin{array}{c}\text { Pola } \\
\text { Spasial }\end{array}$ \\
\hline & 2011 & $\begin{array}{l}\text { Kecamatan Teluk Ambon di Negeri Laha(50), Negeri } \\
\text { Tawiri(49) dan Negeri Hative Besar(48). } \\
\text { Kecamatan Teluk Ambon Baguala di Negeri Passo(39) dan } \\
\text { Kecamatan Leitimur Selatan di Negeri Hutumuri(21). }\end{array}$ & High-High \\
\hline & 2013 & $\begin{array}{l}\text { Kecamatan Teluk Ambon di Desa Poka(44) dan Desa } \\
\text { Hunuth(43). } \\
\text { Kecamatan Teluk Ambon Baguala di Kelurahan Lateri(38), } \\
\text { Desa Latta(37) dan Negeri Halong(36) }\end{array}$ & High-High \\
\hline & 2015 & $\begin{array}{l}\text { Kecamatan Teluk Amon Baguala di Negeri Halong(36). } \\
\text { Kecamatan Sirimau di Negeri Soya(22). } \\
\text { Kecamatan Nusniwe di Negeri Nusaniwe(3) dan Negeri } \\
\text { Latuhalat(1). }\end{array}$ & High-High \\
\hline & 2017 & Kecamatan Teluk Ambon Baguala di Kelurahan Lateri(38). & High-High \\
\hline & Peramalan 2020 & $\begin{array}{l}\text { Kecamatan Nusaniwe di Negeri Latuhalat(1) dan Negeri } \\
\text { Seilale(2) dan Negeri Soya(22) di Kecamatan Sirimau }\end{array}$ & High-High \\
\hline
\end{tabular}

Hasil analisis pola spasial high-high dapat digunakan sebagai bahan masukan dalam proses pengambilan keputusan untuk menjadi fokus dalam pengawasan kawasan lindung.

\section{KESIMPULAN}

Berdasarkan pembahasan di atas, maka dapat ditarik kesimpulan yaitu terdapat korelasi spasial dalam tingkat perubahan penutupan lahan kawasan lindung di Kota Ambon. Korelasi yang terbentuk semakin melemah ditunjukkan dengan nilai indeks Moran's I pada tahun 2011 berubah dari 0,283362665 menjadi 0,059182736 pada tahun 2015, korelasinya melemah namun masih positif. Pada tahun 2017 indeks Moran's I menjadi -0,042523054 yang merupakan korelasi negatif. Selanjutnya hasil peramalan pola spasial pada tahun 2020 menunjukkan korelasi negatif dengan nilai indeks Moran's I-0,011095491 dengan pola spasial high-high yang terbentuk pada Negeri Latuhalat dan Negeri Seilale pada
Kecamatan Nusaniwe serta Negeri Soya pada Kecamatan Sirimau.

Penelitian selanjutnya diharapkan dapat menggunakan metode lain untuk melakukan analisis lanjutan sebagai bahan perbandingan antar beberapa metode autokorelasi atau lebih berfokus pada peramalan dan membuat perbandingan metode dalam proses peramalan.

\section{REFERENSI}

[1] Pemerintah Republik Indonesia. (2007). UndangUndang No. 26 Tahun 2007 tentang Penataan Ruang.

[2] Das, M. \& Gosh, S.K. (2016). A Cost-Efficient Approach for Measuring Moran's Index of Spatial Autocorrelation in Geostationary Satellite Data. International Geoscience and Remote Sensing Symposium (IGARSS). Beijing.

[3] Ma, J., Yang, W., Pan, Y. \& Xu, J. (2018). Analysis of Land Use Patterns and Human Causes Based on Spatial 
Autocorrelation. 26th International Conference of Geoinformatics. Kunming.

[4] Hsu, W.L., Wang, Y.C. \& Lin, K.F. (2016). The Path Of Crowd Dominated-Motion Detection Based On Spatial Autocorrelation. International Conference on Machine Learning and Cybernetics (ICMLC).

[5] Lede, N., Weimei, L., Meiying, J. \& Na, L. (2018). Land Use Degree and Spatial Autocorrelation Analysis in Kunming City Based on Big Data. International Conference on Intelligent Transportation, Big Data \& Smart City (ICITBS), pp. 97-100. Xiamen, China.

[6] Yan, M., Tong, Q., Wang, R., Luo, C., Land, W., Gao, Y. \& Pan, Y. (2016). Outliers Detection of Cultivated Land
Quality Grade Results based on Spatial Autocorrelation. Fifth International Conference on Agro-Geoinformatics (Agro-Geoinformatics). Tianjin.

[7] Chun, Y. \& Griffith, D.A. (2013). Spatial Statics \& Geostatistics. London: SAGE Publications Ltd.

[8] Adriana, D.P.Y. \& Loekito, L.H. (2018). Sistem Informasi Peramalan Persediaan Barang Menggunakan Metode Weighted Moving Average. Jurnal Teknologi Informasi dan Komputer, Vol. 4, No. 1, pp. 71-79.

[9] Katalog Badan Pusat Statistik Kota Ambon. (2017). Kota Ambon dalam Angka. 